\title{
TU/e emonownen

\section{Sustainable performance challenges of rural microgrids: analysis of incentives and policy framework in Indonesia}

\section{Citation for published version (APA):}

Derks, M. J. W., \& Romijn, H. A. (2019). Sustainable performance challenges of rural microgrids: analysis of incentives and policy framework in Indonesia. Energy for Sustainable Development, 53, 57-70.

https://doi.org/10.1016/j.esd.2019.08.003

DOI:

10.1016/j.esd.2019.08.003

Document status and date:

Published: 01/12/2019

\section{Document Version:}

Accepted manuscript including changes made at the peer-review stage

\section{Please check the document version of this publication:}

- A submitted manuscript is the version of the article upon submission and before peer-review. There can be important differences between the submitted version and the official published version of record. People interested in the research are advised to contact the author for the final version of the publication, or visit the $\mathrm{DOI}$ to the publisher's website.

- The final author version and the galley proof are versions of the publication after peer review.

- The final published version features the final layout of the paper including the volume, issue and page numbers.

Link to publication

\section{General rights}

Copyright and moral rights for the publications made accessible in the public portal are retained by the authors and/or other copyright owners and it is a condition of accessing publications that users recognise and abide by the legal requirements associated with these rights.

- Users may download and print one copy of any publication from the public portal for the purpose of private study or research.

- You may not further distribute the material or use it for any profit-making activity or commercial gain

- You may freely distribute the URL identifying the publication in the public portal.

If the publication is distributed under the terms of Article 25fa of the Dutch Copyright Act, indicated by the "Taverne" license above, please follow below link for the End User Agreement:

www.tue.nl/taverne

Take down policy

If you believe that this document breaches copyright please contact us at:

openaccess@tue.nl

providing details and we will investigate your claim. 


\title{
Sustainable Performance Challenges of Rural Microgrids:
}

\author{
Analysis of incentives and policy framework in Indonesia
}

\section{Abstract}

Rural off-grid electrification systems powered by renewable energy have become popular in the Global South. Unfortunately, many microgrids have experienced trouble during their first years of operation, leading to premature system deterioration. In this paper we trace these problems to institutional issues associated with goal displacement in implementing organizations and, relatedly, ineffective programme upscaling, which have remained under-researched in the rural renewable energy literature thus far. Using literature about implementation of large infrastructure projects, political economy of policy making, and replication of innovations as our conceptual lens, we examine a government-initiated microgrid programme in Indonesia. Early project failure was found to be linked to a one-sided policy focus on expanding the number of installed systems, instead of ensuring service quality. This focus is driven by political campaign strategies in which microgrid technologies are used as instruments for political legitimation, and pressure from aid donors to achieve early quantifiable results. It leads higher governmental echelons to care about reaching pre-set installation targets rather than ensuring that lower-level governments face incentives to focus on maintenance and repair. The focus on quantitative expansion also explains a lack of incentives or pressures to address a persistent lack of clarity about responsibilities of each government level, local communities, consultants, and contractors. Similar patterns can be noted in other countries, suggesting the findings have broader relevance for understanding key determinants of microgrid unsustainability in the Global South. To improve governance, pressure needs to be brought on the government by the general public, academia, NGOs and the press through increased public exposure of early system deterioration. These actions should be grounded in research that seeks to understand the complex causes of the problem, considering the whole scope of interlinked incentives and policies, before trying to tackle it. 
Keywords: Rural electrification, energy policy implications, Indonesia, goal displacement, replication strategy, upscaling

\section{Introduction}

Thinly populated rural areas in the Global South are generally isolated and have restricted access to basic amenities (Sahn and Stifel, 2003). Due to high costs, there has been limited progress in electrifying these regions through central grid extension (Mandelli et al., 2016). This has drawn attention to electrification through decentralized technologies like Solar Home Systems and microgrids powered by renewables (e.g., Sovacool and Drupady, 2012; Welsch, 2013; Bhattacharyya, 2012; Mandelli and Mereu, 2013). The EIA (2017) estimates that decentralised systems are the most costeffective solutions for over $70 \%$ of those who will gain electricity access in rural areas up to 2030 , while off-grid and microgrid systems will provide the means for almost half of that new access.

However, evidence is accumulating that the sustainability of the energy services offered by many of these systems has left much to be desired, creating doubts about their effectiveness, efficiency and suitability (e.g., Brass et al, 2012; Kumar et al., 2019; Berger, 2017; Feron, 2016; Green, 2003; World Bank, 2005; Retnanestri and Outhred, 2013; Ikejemba et al., 2017; Ferrer-Martí et al, 2012; Kirchhoff et al., 2016; Nieuwenhout et al. 2001). These studies, mainly based on project evaluations, point to a variety of reasons for off-grid system failure and underperformance, especially for microgrids, which are organizationally and technically more complex than household systems. They point to the neglect of locally-appropriate design, maintenance budget, deficient participation and capacity building, lacking sensitivity and adaptability to local specificities, and unclear actor responsibilities (CosgroveDavies and Cabraal, 1994; Ranzanici, 2013; Palit and Chaurey, 2011; Palit and Bandyopadhyay, 2017; Odarno 2017; GVEP 2011; Sovacool, 2012; Guerreiro and Botetzakias, 2018; Ulsrud et al, 2018; Sato et al 2017; Dauselt, 2001). Despite this growing body of evidence about bad practices, the same weaknesses in project design and implementation keep being replicated in new rural electrification projects. Recent papers (e.g., Kumar et al, 2019; Ikejemba et al., 2017; Marquardt, 2014; Valer et al., 2017) still signal the same problems already identified over two decades ago, 
especially the tendency by project implementers to "drop [technical installations] and go" rather than focusing on sustained delivery of energy services (Kumar et al., 2019).

In this paper we investigate reasons for the continuation of these problems. We argue that the observed sustainability problems in the literature are symptoms of deeper systemic institutional problems that give rise to an inadequate policy and incentive system that discourages project stakeholders to focus on project sustainability. Many of these institutional features are deeply entrenched in society and therefore hard to overcome. They derive from the ways of functioning of government bureaucracies and donor organizations, and are frequently intertwined with issues of politics and power. We agree with Marquardt (2017) and Gollwitzer et al. (2018) that the debate about rural electrification has been dominated by technical and economic challenges, while institutional and governance issues including links with politics need more attention. Accordingly, the goal of the paper is to delve into this deeper institutional layer in order to increase understanding on the nature of these deeply embedded structures and the reasons why they exist and persist, and how they affect service delivery in rural microgrid electrification projects.

A large government-directed rural microgrid programme in Indonesia is examined as an example. Whilst differences in policies, culture, and governance systems among countries within the Global South prevent a straightforward translation of findings beyond the Indonesian context, we will establish its wider relevance by linking it to scattered information from literature about the importance of similar governance issues in other settings. In this way, we attempt to derive lessons that are more widely applicable to different countries struggling with sustainable implementation of microgrid projects.

Indonesia was chosen as a case since it comprises approximately 6000 inhabited islands, making decentralized electricity systems a very attractive solution for electrification. With around 260 million people it is the fourth-most-populous country in the world, and the highest energy consumer in Southeast Asia, accounting for about $36 \%$ of the total regional energy demand. Its government has adopted various incentives and projects to promote the use of renewables since several decades ago, 
which still have not had the intended impact (Tumiwa and Imelda, 2014; Marquardt, 2017; Sato et al., 2017; Global Business Guide Indonesia, 2014b).

In section 2, we briefly review important insights about institutional and governance problems from extant rural electrification studies in order to bring out the specific knowledge gap that we engage with. We also look at some broader contextual literature about other fields of infrastructure such as education, health, water, and sanitation, where highly similar problems are discernable. We build a conceptual framework for our case analysis in Section 3. In Section 4 we discuss the data gathering and processing methods. In Section 5 we introduce essential contextual information for the Indonesian case and we present and interpret our case findings from the perspective of the analytical framework. Section 6 concludes, and suggests recommendations for improving the regulatory framework and institutional system surrounding microgrid projects.

\section{Governance impacts on project sustainability}

\subsection{Insights from rural electrification literature}

To the extent that studies on rural off-grid electrification in the Global South have touched upon the importance of institutional governance issues, they consistently point to similar problems. These essentially revolve around a need for competent, transparent, and responsible project planning and accountable implementation based on clear structures and rules. For instance, in a study spanning problematic rural energy projects in different sub-Saharan African countries, Ikejemba et al. (2017) note the lack of systematic planning by government, citing examples of confused and overlapping responsibilities, responsibility gaps between government and other project actors, and between different levels of government. Attention, funds, and motivation for addressing maintenance and repair and ensuring local 'ownership' of systems become victimised in these situations. Gollwitzer et al. (2018) even conceptualise rural electrification systems as a type of Common Pool Resource to explain such problems of neglect. Ulsrud et al. (2018) highlight ambiguities in policies, regulations and funding mechanisms for village scale solar power in India. Palit and Bandyopadhyay (2017) similarly identify the absence of a robust, socio-politically appropriate governance structure which links different government levels and which is transparent, clear, and unambiguous as the main reason for 
common microgrid failure in India. Mawhood and Gross (2014) point to wavering political commitment, conflicts about goals and responsibilities between involved institutions, and a general lack of institutional capacity in Senegal. Urmee et al. (2016) and Marquardt $(2014,2017)$ highlight the importance of overcoming problems of inter-stakeholder coordination and fragmentation in Indonesia and the Philippines. Sovacool (2012), surveying evidence from different countries, notes that ineffective programmes fail to allocate roles and responsibilities clearly across different actors in line with their capacities, interests and mandates. In this way actors can get tied down in conflicts over who should do what, leading to inaction. Valer et al. (2017) observe similar issues for Brazil specifically.

Yet, growing awareness about the importance of governance structures and procedures has not led to a widespread improvement in project practices and effectiveness. Of course, such awareness needs some time to spread. However, we also note that the above studies still fall short of providing concrete, actionable lessons for improvement. They largely lack details about the specific institutional and governance arrangements that contribute to early project failure, how that happens, and where scope for improvement might exist. For microgrids in particular, still no model for sustainable management is said to exist (Gollwitzer et al., 2018). Only a few studies convey a glimpse of what could be at stake here: Marquardt $(2014,2017)$ refers to governments pushing hard targets for political or financial reasons, giving rise to a drive to maximize installed generation capacity at the expense of ensuring that the installed systems keep working and delivering benefits. Collection and sharing of performance feedback is neglected, leading to repetition of mistakes and inefficiencies in new projects. Valer et al. (2017) note an overriding concern with fast programme rollout at minimal system cost. In combination with inadequate performance feedback, this leads to actor incentives to produce designs that lack robustness and local adaptability.

Aside from these few examples, which lack detail with respect to the analysis of the root causes of the observed policy priorities and resulting behaviours, and which also are not undergirded by relevant policy theory, by and large the rural electrification literature has given short shrift to institutional and governance challenges. The literature essentially observes systems that are not working because of 
'inadequate governance issues', but has not investigated deeply into what exactly is wrong with that governance and why; and how this affects project processes and outcomes.

\subsection{Insights from other public service delivery literature}

Governance failure has been analysed more extensively in studies about public service delivery in other infrastructure fields, both in developing and developed countries. Literature focusing on roads, irrigation, sanitation, water supply, education, and health provides some useful insights about governance structures, procedures and processes. This could hold useful insights for electrification as well. Infastructure projects of various types appear to share some essential common features that are associated with problems. Pritchett and Woolcock typify such projects as "the mother of all institutional, organizational and design problems" because of their high complexity (2004:196), while Edwards conceptualises them as Large Technical Systems for the same reason (2010:9). Pressman and Wildavsky (1973) highlight their long time horizons, resistance to uniform implementation across different local contexts, and need for decisions and extensive coordination across many different actors. The chains between causes (policy design) and consequences (the ultimate goals) are often long, complex, and underspecified. It is especially hard to concretize the end goals. There can be many decision points along the way, each involving extensive dialogue and bargaining between constituencies with different aims and priorities, which can be a source of significant delays and cost overruns.

Moreover, there are crucial links with politics (Benitez et al., 2012; Wild et al., 2012; Paul, 1982). When policymakers and bureaucrats have personal motivations that make their focus deviate from the pursuit of societal welfare, infrastructure policies may be biased, rendered ineffective, or even result in perverse outcomes. Infrastructure projects can be considered successful by some from a political angle, while simultaneously being considered a failure by others from the perspective of efficient public service delivery (McConnell, 2017). The fear of not being re-elected may drive a politician to focus primarily achieving visible results from projects in the short run, deviating from the goal of longterm societal wellbeing. For the same reason, government actors may disregard or suppress the gathering and sharing of performance-related information - the problem noted in Marquardt (2014). 
These works provide us with valuable insights into governmental and political challenges that tend to occur in large public service delivery programmes in general. However, they lack detail into the particular policy and incentive structures leading to failure of programmes in the field of rural electricity provision specifically. This is the gap that we seek to explore in this paper.

\section{Framework for Analysis - Governance constraints to}

\section{sustainability}

In this section we derive a conceptual toolkit with which we can study the problem in more detail and which allows us to identify specific policy and incentive structures that lead to failure of rural energy infrastructure programmes in the Global South. The toolkit embodies two areas: goal displacement and replication of innovations.

\subsection{Program complexity and goal displacement}

Many infrastructure programs have multiple (sub-)goals, with different goals assuming importance for different government departments (Grindle et al., 1980). This leads to coordination complexities due to fragmentation. Moreover, many goals are ambiguous, immeasurable, long term, and difficult to achieve through rational technical solutions. Policy makers and bureaucracies cannot operate on such complex problems that involve disagreement about norms and values, and for which the resources and instruments are not seen to be readily available (Hoppe, 2011). Yet, inaction is also not an option, given societal pressures to deliver. Decision makers will thus look for ways to take shortcuts and to economise on information requirements, involving the narrowing of goals into targets stating acceptable levels of achievement in specified dimensions (Noorderhaven, 1995). Political priorities take over - the focus becomes concentrated on activities that will yield maximal short-run, measurable results because "...immediate results have a political utility for the organization regardless of the contribution that such activity makes to the long-run success of the program" (Quick, 1980:57). What adds to this inclination is the need to spend resources on time, otherwise there could be negative job performance reviews and future budget cuts (Pressman and Wildavsky, 1973:138). 
Politicians and senior bureaucrats can score politically by, e.g., attending public ceremonies to celebrate the completion of a new piece of infrastructure, or regularly reporting statistics with impressive numbers of new technical installations that confirm that the government is 'on target'. This is what will impress the constituencies that matter: whether these be voters in a democracy (Jasanoff and Kim, 2015), or the president or an army general in an autocracy (Quick, 1980). Such actions convey that the government is effective in getting things done for them. Project monitoring and evaluation will be neglected or even actively suppressed, as it could lead to the surfacing of performance information that might shed a less rosy light on the government's activities (Quick, 1980).

The tendency of people or organizations to focus on maximizing short-term quantitative output scores, rather than on the outcomes and developmental impacts of a programme is commonly known as goal displacement (Warner and Havens, 1968; Resh and Marvel, 2012; Bedeian, 1980; Bohte and Meier, 2000). It usually occurs under the influence of complexity and intangibility of ultimate goals, combined with adverse incentives or pressures from above. Bohte and Meier highlight three common forms of goal displacement which can also occur in combination:

1. Cutting corners: If an agency has limited resources, it is likely to focus on generating outputs without considering their quality.

2. Withholding information: Since overseeing agencies cannot monitor every step taken during project implementation, agencies can keep coordinators ignorant of disadvantageous information.

3. Biasing samples: Agencies can also cheat by selecting only successful programme implementation cases for evaluation.

Agency staff might engage in goal displacement since poor performance can result in negative attention from political officials, legislators, the media, and so on, while improving outcomes and impacts is difficult, time-consuming, and not rewarded, especially not in the short term. Overwhelming task demands and low level of bureaucratic monitoring (which makes cheating easy) can also play a role. This is why organizational cheating occurs more in decentralized structures, like those in Indonesia's government, where monitoring is difficult. Agencies face the dual pressure of solving a 
complex problem while simultaneously trying to ensure a high score on performance indicators to please higher-level government officials.

Goal displacement can result in failure to allocate responsibilities and lack of accountability, with serious consequences for project effectiveness, particularly as it concerns responsibilities for guaranteeing the provision of sustainable services from a project intervention after the physical infrastructure has been put in place.

\subsection{Challenges of innovation replication}

An important aspect inherent in the execution of many international development programs, is that they aim for the wide replication of a particular developmental 'product' based on small-scale technology. Thus, reaching programme goals requires extensive replication of the same local project in different locations. Goal displacement can affect such replication, as detailed below.

In the case of rural infrastructure projects such as decentralised energy delivery, the 'product' to be replicated is not only a technical system but also an organizational model for delivering a particular service (Paul, 1982). Insights into the question of what scaling and replication of such 'product offerings' involve come from the fields of business studies and development studies focusing on innovation. Innovation here refers to the whole of technological components intertwined with organizational, political and cultural dimensions of a new product offering (cf. Paul, 1982). Commonly, two main innovation phases are distinguished. First, during innovation exploration or discovery, an initial prototype of the 'product' is developed, typically involving the construction of an early, imperfect best-bet design. This is improved gradually through pilots in which the design is tested and refined in a particular environment, involving interactive learning-by doing among the involved stakeholders. The second phase of replication (also called upscaling, or exploitation) begins once the prototype design has become more or less robust (Winter and Szulanski, 2001; Braa et al., 2007; Bachmann et al., 2013; Foster and Heeks, 2013; World Bank, 2003; Korten, 1980). This is not a matter of simple copying of the developed design in new locations. "It requires the capability to recreate complex, imperfectly understood, and partly tacit productive processes in carefully selected sites, with different 
human resources every time, facing in many cases resistance from proud, locally autonomous agents" (Winter and Szulanski, 2001:731).

Learning from performance feedback is pivotal in both phases. In the exploratory phase, learning aims towards achieving a workable technical and business-model prototype in a few limited settings. By contrast, in the early phases of replication the organization has to learn which attributes are replicable across locations, together with the knowledge of how these attributes are created. This knowledge is referred to by Winter and Szulanski as the "Arrow core". It is typically created by formulating tentative hypotheses from experience of what is probably worth copying during new replications, and then testing these hypotheses in practice, followed by evaluating the performance feedback. This leads to iterative refinement of the organization's Arrow core (or core processes) over time. In later stages of innovation replication, the application of these core processes becomes increasingly routinized. At the same time it is emphasized that complete standardisation cannot be achieved. Some local tweaking will always remain necessary for successful local embedding in response to local social, physical, cultural, and economic peculiarities. Hence, organizations must also master procedures for continued efficient and flexible adaptation around their core processes. This is done through continued learning through performance feedback generated by doing new replications as programme upscaling proceeds.

Local adaptation can present significant challenges. Many rural infrastructure services - including electricity - do not spontaneously elicit sufficient effective demand that will recoup their full costs. The sustainability of project services may come under threat from unviability. The willingness and ability to address such issues by the project parties should therefore be an integral part of project replication. Hence, replication poses the maximum challenge to the strategic and operational management of a program. While the scale of project operations is greatly increased, one cannot make do with straight copying of procedures from the prototype phase (Paul, 1982). Workloads can then become particularly heavy.

The necessity of core processes, local adaptation and feedback loops to successfully apply a replication strategy, are important for the Indonesian government's upscaling of microgrid 
technologies. Every new infrastructure project can be seen as a replication of an innovation that was implemented elsewhere in the past and is subsequently being replicated in different locations. Rural microgrid projects were already initiated in Indonesia in the 1990s (Jigyōdan, 1993), and have since been replicated widely. To a local community, each replication is an innovation, but at central and provincial levels, it is not. Consequently, one could expect certain core processes of the design and implementation of these replications to be already thoroughly embedded in policy and procedures. Additionally, there should be a feedback mechanism in place on how these policies and procedures are working out at the local level so that they can be further optimised and the core processes perfected over time. Through feedback from each new replication project, policymakers would also be expected to learn effective procedures for tweaking around the core. Therefore, we will examine the core processes that need to be embedded in policy and procedures for proper replication of energy infrastructure projects, the local adaptation necessary for local embedding of the innovation and the feedback loop necessary to further optimise policies and procedures.

Summarising, two key elements appear to be essential to understanding persistent governance problems affecting the sustainability of rural infrastructure projects, including those focused on electrification. These are: (i) goal displacement, and (ii) challenges of replicating a prototype 'product offering', especially missing feedback loops. There are also important links between the two: adaptive replication in the upscaling phase of a programme can lead to heavy task burdens on project staff, increasing pressures on them to cut corners. Goal displacement might occur especially when this occurs in an organization where there are already incentives from above to prioritize quantity over quality. This, in turn, impedes learning through performance feedback, which is so essential for successful replication.

\section{Methodology}

The analysis of incentives and motives leading to premature failure of microgrids in Indonesia through goal displacement and replication failure is based on primary data, supplemented by information from existing studies about Indonesia's rural electrification programme and its governance more broadly. The attractiveness to work with decentralized electricity systems for Indonesia, the largest archipelago, and the efforts the government has put into such electrification projects, without reaching 
the intended impact, are the reasons why Indonesia was chosen as a case study. Moreover, there was some prior evidence of prioritization of short-term quantitative performance targets in that context (Marquardt, 2017; Afifah, 2016; Blum et al. 2013).

The collection of the empirical evidence was an iterative process. After a broad exploratory literature review which surveyed common causes of early failure of rural renewable energy projects in the Global South, a first round of field research was undertaken spanning three microgrid systems in Yogyakarta Province on Java island during Sept-Nov 2017. Yogyakarta Province on Java island was chosen since existing relations with Universitas Muhammadiyah Yogyakarta (UMY), which was the host of the 1st author of this paper, made it possible to find officials on various government levels that were willing to talk about sensitive problems surrounding microgrids in their province, without fear of repercussion from their superiors. Furthermore, Java is one of the most developed and organised regions of Indonesia, with the highest electrification and education ratio and income per capita. It could be logically expected that problems with rural grids in lesser developed regions of the country could only be comparatively more severe, or similar at best, but surely not less serious than what we might encounter in our fieldwork zone. Therefore, if we would indeed find evidence of serious governance problems on Java, it would not be unreasonable to assume the existence of a more general problem in Indonesia.

The choice of projects on Java was based on their diversity in generation (two micro-hydro grids, one solar/wind microgrid), diversity in initiation (two initiated by the central government and one by local governments), and existing contacts with staff from our local host university. It was decided to go for in-depth exploratory interviews in just three project locations rather than adopting a standardised survey approach covering a larger number of projects, because at this stage it was necessary to probe the nature of rules, regulations and informal institutional arrangements and how these affected incentives faced and behaviour adopted by project staff and other involved stakeholders. Interviews were conducted personally by the first author of this paper assisted by a local UMY staff member, with local and provincial government officials, local operators and local communities, supplemented by direct observations of the handling and technical performance of the systems. The interviews followed a semi structured format with an interview guideline that was constructed beforehand, which consisted 
of open questions about procedures on how the projects were initiated, designed, planned, installed and maintained. The largest grid location was visited repeatedly, enabling cross-checking of findings and more in-depth follow up questions to be asked. The interviews, which lasted at least one hour, focused rather broadly on (dis)incentives and motives of the actors involved with the energy system that make them deviate from keeping the systems in working order after installation, inspired by the main findings from our literature review of rural electrification literature and common infrastructure problems as detailed in section 2. The interviews were later transcribed and the resulting field report was checked with the assisting UMY staff member.

The interview transcriptions from this first round of field work were analysed for common patterns in incentives and related behaviours, and how these affect sustainability outcomes. Certain recurring project features were identified during this process, which caused lack of maintenance planning and budget, neglect of local capacity building, and lack of feedback about technical problems. It also emerged that these problems were already recognised among the interviewees themselves, but they had not taken action to improve matters. This raised the question, which we also began to ask from the rural electrification literature at large, why certain issues are widely recognised as problematic and yet remain unresolved, and even become replicated again in new projects. At this point we developed a tentative hypothesis that certain incentives, motives and behaviour could be intractable because of high programme complexity and links with politics, which could cause a persistent diversion of focus from project sustainability among programme stakeholders. We then set out to uncover the nature of these deeper problems.

A new literature review round was undertaken, focused specifically on this issue. It was at this stage that the goal displacement concept was adopted as a core focus point in the research, combined with issues of replication of innovations. These phenomena, in combination, became our main conceptual guiding frame as set out in section 3 . The issues explained in the studies discussed in section 3 appeared to explain and helped to interpret what we had observed in the first fieldwork round, and in interviews [1],[2],[3],[4] and [5], which were conducted in preparation for the second field visit to Indonesia. This led to the formulation of a more detailed hypothesis about the causes of the lack of focus on project sustainability at various governmental levels, specifically relating to major causes and 
consequences of goal displacement and project replication failure. This hypothesis was expressed in the form of a draft flow chart, showing how different causes were most likely interconnected and how they jointly gave rise to a lack of focus on sustainable performance.

To test the hypothesis, a second fieldwork round was conducted during two months in spring 2018. The aim in this round was mainly to verify if our hypothesis could be confirmed by actors in the Indonesian government, actors in the Dutch government (i.e., a large donor to Indonesia in the field of renewable energy projects), experts in renewable energy consultancy companies, NGOs, and Indonesian academics through interviews in which we sought to ensure the wider validity of our findings from the initial three project locations. New fieldwork in one of the microgrid locations was also carried out. Some of the interviews involved in-depth discussions lasting several hours. Government officials from various districts on Java where interviewed as well as officials in the national government and related agencies. These interviews were particularly crucial, since these government actors deal with hundreds of microgrid projects in their area and were thus in a good position to comment on the wider validity (or otherwise) of our limited project case study findings. The interviewees were chosen based on connections to UMY and referrals from previous interviewed stakeholders which ensured their willingness to openly talk about problems surrounding rural electrification in Indonesia, which is not easy to achieve.

Furthermore, discussions were held with government officials and an academic energy expert from another, less developed province, West Nusa Tenggara. It has its own provincial microgrid programme and its own demographic and geographic challenges, but was found to encounter the same types of institutional and incentive problems with rural electrification projects as what had been found on Java. The flow chart was repeatedly updated during the second round of interviews to incorporate emerging new insights; the final version is found in Figure 3. This fieldwork round consisted of more structured interviews, with a clear interviewing guide, which focused on understanding and checking the cause-effect relations hypothesized in the flow chart. The interview format still left room for interviewees to add, digress, and elaborate on aspects they deemed important. 
The two fieldwork rounds together comprised 24 interviews of which 22 were one-on-one and two took the form of focus group interviews with two and five persons respectively (Table 1 for details). The latter format sparked some discussion among the interviewees and helped participants to be more open and reflective about policies and regulations. When used as sources in section 5 , the interview numbers are indicated in square brackets.

\section{Results}

\subsection{Background to the Indonesian case}

This sub-section provides brief information about the Indonesian energy sector and the procedure of microgrid construction and implementation. This is necessary for understanding why and how goal displacement arises and how it impacts on system sustainability, discussed in section 6 .

Indonesia has already implemented numerous microgrid projects. This has been done through government initiated programs, since the state-owned electricity company PLN has had difficulties in electrifying rural areas for various reasons (Wells, 2007). Since the islands of Java, Madura and Bali account for roughly $80 \%$ of total power consumption, most of PLN's investment capital is spent there. Electrifying remote regions is also unprofitable for PLN (PwC, 2017). Private sector involvement in electrification of rural areas also has remained limited due to highly uncertain cost recovery and restrictive regulations. Government-initiated microgrid projects often involve various parties such as provincial and local governments, energy consultancy firms, construction companies and universities. Indonesia has a complex, heavily decentralized governmental system (Global Business Guide Indonesia, 2014b; Marquardt, 2017), which means that several layers of government are typically involved. The government consists of five administration levels; central government, provinces, districts, sub-districts and villages. This structure has been claimed to have advantages because it brings local governments (everything below the provincial government) physically close to the concerns of their constituencies, and facilitates local-level revenue generation and service delivery (Lewis and Smoke, 2017).

Yet, as in many other developing countries, many microgrid projects in Indonesia already experience problems during their first years or even months of operation, arising from lack of a maintenance 
budget, problems with task and responsibility allocation, and insufficient participation and capacity building (Shezan et al., 2017; Mehang et al., 2016; Schmidt et al. 2013; Yanoto, 2011; Putra et al., 2017; Sato et al., 2017; Retnanestri and Outhred, 2013; Blum et al., 2013; Yurnaidi, Z., 2010; Wahyuni et al, 2013; Nugroho et al., 2017; Guerreiro and Botetzagias, 2017; Ranzanici, 2013; Purwanto and Afifah, 2016; Afifah, 2016). So far, this accumulating failure evidence at project level has not resulted in significant change in the way projects are initiated and executed. Analysis of how national policies influence project implementation at the local level can generate insights on why these problems endure, by bringing to light the complex web of policy and procedures that limit the effectiveness of government agencies and individuals within it.

\subsection{Procedure for rural microgrid construction projects}

Since 2017, the process of electrification through off-grid systems involves the following steps.

Step 1: A hamlet seeks electrification through an off-grid system, submits a proposal.[1]

Step 2: The proposal is sent to district and provincial governments, who review it and prepare a budget. The proposal and budget are submitted to the central government for DAK funding.[2]

Step 3: When DAK funding is received, additional feasibility and design studies are conducted by an independent consultant, the hamlet residents are acquainted with their tasks and duties, and land permits are issued.

Step 4: The project is put out to tender online by the National Procurement Agency (LPKK). The company that wins the tender constructs the micro-grid and trains local residents appointed by the hamlet to operate and maintain the system.

During construction, there is no coordination between the contractor and the consultant who conducted the feasibility and design studies unless specifically requested by the contractor. It is mandatory to have another consultant supervise the work of both the consultant who carried out the studies and the contractor. However, this role is almost always executed by either provincial or district governments, which enables them to keep $5 \%$ of the total construction budget.

After a micro-grid has been constructed, the local community is supposed to be responsible for operating and maintaining it. The above-mentioned project studies show that most problems in 
Indonesia arise at that stage, although it should be noted that these studies have reported on the result of a previous top-down DAK disbursement format, in which local parties were not involved in the proposal writing. This procedure was changed in 2017 and the outcome from this policy modification is not yet widely observable. However, our interview respondents indicated that they did not believe that the changed procedures had substantially improved the situation, because they were still facing the same old battle with bad quality of installations, which is caused by a focus on price which results in low quality of components and low quality of design. The focus on price leads to insufficient budget available for operation and maintenance as well which also results in rapid deterioration of the microgrid. The lack of task and responsibility allocation highlighted in literature further causes a lack of focus on operation and maintenance -- if anything, these problems have worsened under the new procedure because five different levels of government are now involved in proposal design. In Figure 1 we depict how these observed problems of rural electrification in Indonesia lead to inadequate designs, bad quality of the components and installations, lack of maintenance and therefore eventually to rapid deterioration of micro-grids.

FIGURE 1 HERE

\subsection{Incentives and motives leading to premature deterioration of microgrids in Indonesia}

In this sub-section we analyse the policies, incentives and motives embedded in Indonesia's governmental system, following the analytical framework in section 3. First, we look at the core processes developed in the exploration phase for system design and construction, which are needed for the subsequent large scale replication strategy implemented by the government, and we identify problems with these core processes. Then we zoom in on adaptation processes at the local level during the replication phase. Following this, we analyse which reasons enable or cause goal displacement and how this affects the feedback loop. In the course of the analysis we will expand Figure 1, including newly found reasons for lack of sustainable implementation of micro-grids as we go along. 
Renewable micro-grid projects started in the 1990s with pilots to prove that the systems were viable (Lewis, 2017). The projects were then replicated to electrify remote rural areas throughout the country, while also increasing the share of renewables in the energy mix. At provincial and central levels, these projects are thus perceived as replications of a known concept by now. Only a local community that receives a new microgrid will still experience it as a new innovation.

One would therefore expect that the core processes for design and implementation of microgrids would be embedded in policy and procedures, with just some local tweaking necessary for application in new locations. We found that there are indeed standardized procedures for proposal submission, budgeting, feasibility studies, design processes, tendering, local content and implementation of the project, which can be seen as core processes. New feasibility studies are conducted and a new design is made for every new project, which suggests that the government also realises that local tweaking is necessary for full adaptation of the technology. There are however some problems in the core processes and local adaptation that prevent sustainable implementation of microgrids.

\section{Challenges in core processes}

To prevent mistakes during design and implementation, the central government requires the provincial government to hire an overseeing consultant - the technologies can be difficult for local construction companies to understand without such professional help[4],[7],[9]. Yet, in many cases this does not occur because there is no standard procedure to ensure an overseeing consultant's input. The contractor can meet with the consultant who made the design only through the provincial government. Such requests are hardly ever made and are certainly not the standard. Moreover, for micro-grid projects, which are relatively small, the provincial governments are allowed to do the overseeing themselves, thus retaining $5 \%$ of the total construction budget. This amounts to a financial disincentive to engage an external overseeing consultant. This lack of knowledge within local governments, consultants and contractors causes design and implementation errors, which remain undiscovered until the operational phase. Especially in more remote areas, provincial governments do not have the capacity, knowledge and the resources to do the overseeing properly [9],[10],[12],[14]. Such errors include, but are not limited to, inverters that break down regularly due to overvoltage because of design errors, batteries that are deeply discharged since no proper (dis)charging regime is 
imposed or (hydro) generators that do not have the capacity to deliver the full demand load and therefore break down regularly since they run at full capacity all the time.

Furthermore, the contractor's limited responsibility period is problematic. He can be held accountable and is expected to fix any problems in the system for the first six months of the system's operational life only. The local community and local government have to deal with the consequences of construction errors from then on. Thus, the contractor has no incentive to ensure that the system will be problem-free beyond six months [6],[7],[11],[12],[15].

Another reason for early failures is Local Content Requirement $(L C R)$ regulation that stipulates that every microgrid project should use $30-70 \%$ locally manufactured components, depending on location and type of microgrid. Since local manufacturing has yet to meet international standards, this results in poor-quality components. Alternatively it leads to increased costs, when components are imported as disassembled parts and then assembled in Indonesia to comply with the LCR requirement.

Furthermore, lack of budget for maintenance and repairs (in combination with use of poor-quality components) leads to rapid system breakdown [6],[7],[11],[12],[15]. To make the situation worse, the government pays contractors only for very limited operator training, typically two days, insufficient to carry out proper maintenance or deal with early failures of key components such as heavily deteriorated batteries or broken inverters (Global Business Guide Indonesia, 2014a; Negara, 2016).

The tight annual budget cycle has negative effects too. Local governments have to submit their budgets for the coming year in April of the current year. Therefore, they must complete the feasibility study, design, tendering and construction within one year. The government grant becomes available at the start of the year and should be spent within that year. If some of the money is not spent, the local government's next budget will be reduced. This creates an incentive to spend quickly, limiting the time available for the consultant and contractor to design and construct the system properly (Lewis, 2015, 2017; Lewis et al., 2016). If a local government wants more time for a project, it needs to submit a proposal requesting this, which can be a difficult process and is therefore avoided if possible [2],[3],[9],[11],[15].[3] 
These inadequacies in core processes in design and construction lead to early failures during the large scale roll-out of micro-grid technology. This is aggravated by local adaptation requirements that arise when the microgrids are placed in their specific new local environment, as detailed next.

\section{Challenges with local adaptation}

As emphasized in section 3 , a well-functioning feedback mechanism is crucial for verifying whether a new technology is performing well, the core processes and procedures are working as planned, and local adaptation is effective. However, there are manifold feedback problems in Indonesia's microgrid program. When problems arise with microgrids during the innovation-exploitation phase, local communities rarely step up to get their systems fixed. They are reluctant to spend community money on maintenance and repair. Although every village gets a village fund and most hamlets are also encouraged to set up a fund to repair their microgrids, most villagers do not feel they own the systems and do not feel responsible for them [5],[9],[12],[14],[15]. Indonesians view electricity supply by government as a right, perhaps because of their long, historically-rooted client-patron relationship with the state (McCawley, 2006). Also, local communities are unclear where they should complain to claim their rights. More often, they do not even want to complain [24]. These communities often pay very little for electricity (for example, USD 0.49 per household per month) and do not want their bills to rise. So, they try to keep their systems running with whatever means they have, often in sub-optimal ways. Even when local communities do complain, they are often not taken seriously [5],[8]. Complaining and being confrontational are generally not considered to be polite behaviour in Indonesia's consensual culture (Setiawan, 2018). Insufficient social transparency is also not condusive to good grid functioning in the longer term. Most Indonesians are unaware that many projects implemented and funded by the government are not yielding their intended impact. There is evidence that problems are actually being suppressed. NGOs that evaluate micro-grid projects or programmes are often not allowed to publish their findings online; they can only share their reports with the responsible ministries [14],[15]. Especially during the political campaign season, politicians and senior bureaucrats want to play up achievements and promises in terms of new installations, while performance of existing systems is disregarded 
[14],[15],(Wardhani et al, 2017). All this adds to insufficient pressure from civil society for change due to lack of public awareness [3],[14],[15],(Wardhani et al., 2017).

There are so many different parties involved in each microgrid project that it becomes possible to engage in "passing the buck" behaviour in relation to unpopular repair and maintenance actions, which do not yield evident public relations dividends (more on this in next sub-section) and which are also financially unrewarding. This unclear responsibility allocation makes these activities fall between the cracks, which contributes to lack of system performance information and feedback upwards through the layers of government back to the centre. The central government argues that since it pays for the construction costs through DAK, provincial and local governments should be responsible for funding repair and maintenance through own revenues and taxes.[4] However, most provincial and local governments feel they do not have the financial resources for maintenance and repair and that since the central government financed the construction, it should ultimately be responsible for all project costs and by implication, for the sustained functioning of the systems [5],[9],[12],[14],[15],[20]. As observed by a provincial civil servant in charge of carrying out microgrid projects: 'If we don't receive the money from the Central Government, then what can we do to improve the performance?' [14]. The official central government regulations do specify that the costs are ultimately the responsibility of the provincial government, however the provincial government feels that the responsibility should fall to the governmental body that initiated the project, which in many cases is a local government [14]. Since these regulations are not enforced through reward or punishment and do not specify quality and frequency of maintenance, most provincial and local governments do not comply with this task [2],[4],[7],[8],[9],[12]. This leaves the villagers, who are expected to pay those costs through the village fund they receive every year, and/or through a monthly tariff, but, as already noted, they also have reasons for non-compliance.

Another reason for local government reluctance to spend money on maintenance and repairs - and which therefore contributes to lack of performance feedback - is that central government policies regarding microgrids, rural electrification and renewable energy change every year. These changes aim to simplify procedures, but they frequently create confusion as to what the exact regulations are, what is allowed and what is not [1],[7]. Local government civil servants are afraid of making mistakes 
that could be perceived as corruption. This fear of being charged with corruption creates an incentive to select the tendering contractor offering the cheapest price, which could affect quality. Many civil servants do not know the exact bureaucratic procedures necessary to justify their spending and are therefore hesitant to spend more money on better components or on maintenance and repairs. Maintenance and repairs can be quite expensive in remote locations because of transport costs, while the small size of the microgrids systems and distances between them also prevent the achievement of economies of scale in this activity [1],[3],[9],[11],[14],[15].

Figure 2 depicts how these issues combine to contribute to rapid deterioration of microgrids. It now becomes clear that the problems observed in existing literature and depicted in Figure 1 and 2 are not independent causes of failure. Rather, they are consequences of structural inadequacies in core and replication procedures that lead to a whole raft of incentive problems for project stakeholders.

\section{FIGURE 2 HERE}

\section{Goal displacement}

Ultimately, the structural problems that lead to lack of performance feedback signalled above have even deeper causes relating to goal displacement, to which we turn now. One of these deeper causes is that Indonesia receives development support from various donor organizations, which creates pressures to deliver early measurable, quantitative results at the highest level. This, together with political campaign strategies that use infrastructure installations to win voters (voters, too, reward visible quantitative achievements) has manifested itself in ambitious annual target-setting for completion of new installations within the central government [1],[8]. Within provincial and local governments, too, political campaign strategies exhibit a focus on quantity rather than quality of projects. Since voters tend to favour candidates that are decisive and get things done, local governors care more about numbers than the actual performance of systems. This results in a lack of policy and standards on operation and maintenance at all government levels [1],[8],[9],[10],[11],[12],[14],[15].

Behind these tendencies lies a modernisation-inspired ideology among technocrats, strongly represented in Indonesia's government since independence; modern infrastructure technologies have been widely used for political legitimation purposes in the building of post-colonial Indonesia, and this continues till today (Amir, 2013; Moon, 2015). What adds to the problem is that local rural 
communities that receive the systems and Indonesia's civil society at large are not vocal enough and not encouraged in the first place - to call politicians to account for failures, while NGOs that do try are actively impeded in their efforts towards achieving more openness. This politically-induced lack of social transparency regarding the actual effectiveness of the programme is a major enabler of goal displacement.

The prioritization of quantity over quality [9],[10],[11],[14],[15] is reflected in a policy perspective on energy access defined in binary terms: villages are defined as either having, or not having electricity access, with "access" being defined by having received an installation. No account is taken by the provincial and central governments of reliability, capacity or quantity of the provided energy, or the number of households that enjoy electricity in a village. There is insufficient monitoring to check if villages actually continue to have electricity after installation and no administrative procedure to change their access status if their systems become inoperative [14],[23]. To quote a provincial civil servant in charge of carrying out microgrid programmes, 'It is more important to focus first on the quantity because the quantity is not enough. After sufficient quantity is reached and is more balanced, we can focus on the quality.' [9]. This indicates that this prioritization is a conscious political decision and not merely the result of limited resources: it is politically inexpedient to allocate more resources and effort to repair and maintenance, which could uncover embarrassing evidence of non-functional systems. Furthermore, off-grid electrification is portrayed by the government and the PLN as a temporary solution until the PLN extends the national grid to the area (Blum et al. 2013), although this is realistically speaking impossible within the foreseeable future. With this argument one can justify the disregard of long-term project sustainability [2],[7],[9] (Marquardt, 2017).

The institutional disincentives for system maintenance, and the pressures to realise new systems percolate down the government levels, affect budgets and assessment structures. This is where the prevalent non-compliance with maintenance-related task responsibilities comes from, and also why these responsibilities are not enforced from above. Civil servants at all levels are concerned with avoiding unwanted attention from their superiors for failing to meet their set number of annual new installations. Since most local governments also do not have the capacity, incentives, encouragement, 
funding and knowledge to implement micro-grid projects properly, they feel they have no choice but to cut corners and focus on maximizing "access" as defined by their superiors.

What aggravates the situation at the local level is that within local governments, the governor can appoint the department heads (which is not the case in the central government). This means that the head of the energy department could change after every election, which makes it difficult to make long-term plans and have a clear unified vision on rural electrification and renewable energy. It also means that department heads are often appointed because of their connections rather than their skills and competences [9],[10],[14],[15]. This contributes further to the knowledge gap on renewable energy technologies existing within local governments [4],[7],[9],[14],[15].

Although the department of New and Renewable Energy, within the EBTKE [5] ESDM [6], is aware of these problems, effecting change is difficult. Several central government ministries are involved in rural electrification [7], each with its own vision and goal. Horizontal communication between different line ministries is therefore extremely challenging [8],[14],[15]. Policy reforms for better project implementation from the EBTKE need to be approved by other line ministries. The resulting negotiation process takes much time and limits the efficiency of the EBTKE [14] (Marquardt, 2017). The program is thus organisationally highly complex, involving many different constituencies with their own interests and priorities, and many decision points that need to be passed before any installation can materialise. Four levels of government below the central level are involved in writing the proposal, making it extremely hard to allocate responsibilities for subsequent failures. These are precisely the kinds of conditions in which goal displacement can thrive, according to the literature reviewed in section 3

Goal displacement thus creates a clear lack of accountability among all the involved parties. Due to neglect of service quality, there are no adequate anticipatory policies that stipulate clear procedures and responsibilities for addressing operational problems. To the extent that formal rules exist, they are ambiguous and/or unenforced. Although current central government regulations make the projectinitiating provincial government formally responsible for maintenance, this is meaningless when four different levels of government are involved in proposal writing and when the central government is not 
enforcing. Frequently changing policies and challenging intra-government communication aggravate the confusion, creating a climate of fear in local governments of inadvertently overstepping the rules and being accused of corruption by the local police, the district attorney or the anti-corruption agency. Goal displacement in government also explains why contractors and consultants are not incentivised appropriately by government actors. In general, the lack of policy and procedures on responsibility allocation during the operational phase makes it impossible to hold any party accountable for early micro-grid failures.

In figure 3 these goal displacement-related reasons for microgrid failure are added to the diagram. It can now be seen that performance problems that have been often indicated in the literature on rural electrification are symptoms of deeper institutional problems, which are in turn caused by pressures and incentives to favour quantity over quality.

FIGURE 3 HERE

\section{Conclusions and Recommendations}

The aim of this paper was to pinpoint the incentives and policies within the intergovernmental structure that can affect the sustainable functioning of micro-grid projects, and to investigate important causes of these problems, with an empirical case set in Indonesia. While several existing studies about rural electrification have highlighted the lack of responsibility allocation and lack of technical and organisational capability in governments to implement electrification programmes, this study sought to probe important underlying causes of these problems as they relate to governance structures that have remained under-researched in the literature so far. This was done with a conceptual framework drawn from insights about implementation of complex infrastructure programmes, innovation studies, and organization science.

In the rural micro-grid program analysed in this paper, the replication of micro-grid projects deviates substantially from the ideal model outlined in section 3, in which iterative learning from feedback from each new installation leads to efficient and effective procedures concerning optimisation of core design features and local adaptation of subsequent installations in new locations. Goal displacement 
induced by political pressures, aid donor demands, programme complexity and associated high workloads of implementing government staff prevents proper feedback mechanisms and associated responsibility mechanisms from operating. None of the stakeholders show interest in ensuring that the interventions have the desired social impact, while missing feedback concerning the policies and procedures also leaves the general public incognizant of their ineffectiveness. To the extent that central government actors do know about this, they are not interested enough or not powerful enough to change the status quo. In view of the perceived necessity among the key program actors to focus on expansion of the quantity of systems rather than on the continuity of electricity services provided by these systems, the government actors at all levels lack incentives to improve local capabilities and to change policy in a way that will improve the service quality of micro-grid projects. The focus on numbers prevents reflection among the involved stakeholders and hinders the setting up of effective performance monitoring mechanisms that could lead to improved replication of micro-grid projects in new areas over time. The policies seem to be frozen in an incomplete, inconsistent and inefficient system which serves the politically expedient goal of quick replication of micro-grid installations.

Using the insights from our Indonesian case as a lens to probe the reasons for programme failure elsewhere makes it possible to identify certain common causes that seem to run across different environments. What we can discern is a pattern of problematic underlying incentive structures that favours quick "scoring" based on superficial output indicators and dissuades attention for long term sustainability impacts. For instance, goal displacement very similar to Indonesia's case is evident in India's rural electrification policy with its focus on electricity access of villages, in which a village is declared to be electrified when just 10 household connections have been realised. This creates incentives for implementers to proceed to the next village as soon as they have reached this target threshold (Palit and Bandyopadhyay, 2017). Furthermore, the programme is politicised. In many villages politicians promise free electricity connections during election campaigns. This undermines consumers' subsequent willingness to pay for the services (Fowlie et al., 2018). Similarly, in Brazil there is a politically-induced focus on setting up as many systems as possible at total minimum cost. This compromises system quality and post-installation service (Valer et al., 2017). Meanwhile, in the Philippines goal displacement is manifested in pressures felt by central government actors to realise as many new installations as possible because of international aid donors who want to see early 
tangible evidence of results, so that post-installation maintenance becomes neglected (Marquardt, 2017). In Sub Saharan African countries, where non-government actors take prominent roles in many rural electrification programs, a one-sided focus on maximising system sales at the expense of capacity building for sustainable post-installation service delivery has also been noted (Ikejemba et al., 2017). There are many (social) entrepreneurship ventures that are receiving financing from overseas aid organizations and green investors who are keen to show that they are doing something constructive to foster the "energy transition" towards renewables (Bhamidipati et al., 2019). This can lead to high expectations on the part of the receivers of the funds to deliver quick and tangible positive results, not unlike the situation facing the Philippine government.

Of course, this evidence from other countries is still anecdotal. The authors of the cited studies did not have goal displacement as their main research objective, so they did not gather their data to probe this phenomenon specifically. Still, the scattered information that emerges from the studies appears to point to broad similarities across different contexts, suggesting that the core findings from our Indonesian case may have broader relevance. It would be fruitful to pursue further research aimed at more extensive validation of these patterns in different countries in the Global South.

It would also be beneficial to identify and investigate programs that appear to have avoided the goal displacement syndrome to some degree, to learn how and why they have managed to achieve this. As far as microgrid programs in the Global South go, the authors of this paper are not aware of any truly successful large scale programmes that have managed to circumvent these types of problems. There are some large individual household energy programmes that have achieved remarkable results (for example, IDCOL in Bangladesh) but, Ulsrud et al. (2011) observe, these operate at different societal scales and have different ways of technology implementation of operation, different features of electricity services delivered and, because of this, distinct needs for social organization of the systems in local communities and institutional frameworks. Therefore, we do not think that insights from solar home systems programmes are readily comparable with programmes such as Indonesia's microgrid scheme. 
The best record of microgrid programmes to date appears to lie with small to medium-sized initiatives run by non-governmental organizations, such as Gram Oorja in India which had installed approximately 60 microgrids systems (by August 2018) in remote areas in collaboration with local NGOs, using CSR funds from large private companies. What one can learn from this case is that its social business model comes with a very clear division of responsibilities and roles, with Gram Oorja functioning as the hub for technical expertise and as the financial sourcing agent, while the NGOs use their strong local presence and trusted relations in the villages to take care of capacity building for organization and maintenance and fostering a strong sense of ownership of the systems in the village communities. Notably, villagers maintain high payment discipline because problems with the electricity supply are quickly attended to, and this prevents the social and financial support base from unravelling (Katre et al., 2019). This holds another major lesson, because it puts a different perspective on the supposed lack of purchasing power as a major cause of failure of rural electrification projects in economically deprived areas, as it is often portrayed. Rather, poorly functioning systems demotivate users and can cause them to abandon the systems to their fate, leaving an ever smaller number of people to contribute to their upkeep until these people too, have to declare defeat. Of course, unsubsidised fee structures of rural decentralised systems can present a financial bottleneck in some environments, but the Indian examples - which are drawn from remote tribal areas with a high incidence of poverty - suggest that financial viability can be achieved and maintained through strategies in which attention for long-term service reliability is incentivised properly. This effectively tallies with our findings from the Indonesian case, where financial viability unraveled because such incentives were not in place. However, an important question that comes to mind in relation to the Indian example is, to what extent projects with organizational models that achieve this can be widely replicated. They are by definition labour-intensive and rely on strong local embedding. It seems an effective model on a smaller scale, but it remains to be seen if the programme can grow much bigger without losing precisely those essential features that make it effective. And for sure, the model cannot extend into areas where suitable NGOs do not operate, or at least it would take many years to get established.

The comparative success of the Indian example compared to our Indonesian case also raises a further question, namely whether private sector-led initiatives or multi-sector partnership programmes 
are the preferred way forward for rural microgrid projects. In this respect, it is important to be mindful that government institutions are not the only organizations that can fall victim to goal displacement. Programmes led by NGOs and private entities can equally stumble: much depends on who pulls the purse strings, the extent of financial dependency of the implementing organization, the financing conditions, and of course, the strategic interests of the financing entity. Many foreign aid sponsors are intent on companies or NGOs achieving visible "quick wins", to prove the success of a certain concept that they are keen to champion. The ever greater popularity of results-based financing mechanisms within the international aid community appears to bear this out (Thomas, 2016). In relation to projects dealing with infrastructure-based services like electricity, it is a big challenge for such financing programmes to define "success" criteria in such a way that the implementers are properly incentivised to ensure long-term service quality. In such a setting, it is not so easy to identify constructive ways forward.

It is generally difficult to prevent goal displacement. Adding more rules to prevent organizational cheating would most likely only result in more efforts to circumvent the additional rules, which would create a vicious cycle. A better way to deal with the problem would be by pursuing a better understanding the full set of goals an organisation is striving to achieve, and how incentive and policy structures and performance indicators can lead to goal displacement. Pressman and Wildavsky (1973) suggest that the long chains that connect the proposed solutions to the problem should be investigated, so that it becomes transparent where a program can go off-track due to a lack of logical connections. In any case, rewards and penalties should be based on more than just short-term performance criteria. But this probably requires external assistance for, and pressure on involved organisations, since the responsible agencies have no internal incentive to change the status quo. The question then arises who can bring such authority to bear on them. Powerful aid donors could potentially play a role, but they themselves are often suffering from goal displacement too, adding to the problem rather than the solution. In view of this, we do see a constructive role for increased collaboration and dialogue between financial aid donors and independently funded researchers to improve understanding about, and create greater awareness of how donor financing conditions can shape behavioural incentives of receiving organizations in the Global South. It is hopeful to note that some donors are beginning to welcome such initiatives (for a recent example, see Frobisher, 2019). 
Also promising in the longer term is the stimulation of awareness among involved program stakeholders locally, based on better information. This is where independent media, critical NGOs, and academics who are financially independent of aid organisations or governmental programs can play a useful role in educating civil society and empowering local rural communities, and in this way bringing pressure to bear on program-implementing parties. It can help foster the understanding of all aspects of the problem - as a complex system of intertwined issues of causes and consequences and to foster the drawing up of common goals, big-picture thinking and a long-term focus. It could be helpful for parties to work with a flowchart such as in Figure 3 to identify the policies and procedures that are the root cause of system failure and those that are mere symptoms thereof; it can also help them to realise that tinkering with one aspect without considering the broader system will not result in significant change. 


\section{Appendices}

Table 1: List of interviewees

\begin{tabular}{|c|c|c|c|}
\hline No. & Position & Organization & Type \\
\hline 1 & $\mathrm{PhD}$ & Dutch University & Interview \\
\hline 2 & Junior Consultant & Indonesian NGO 1 & Skype interview \\
\hline 3 & Senior Advisor & Dutch Central Government & Interview \\
\hline 4 & CEO & Dutch NGO 1 & Interview \\
\hline 5 & Senior Policy Advisor & Dutch Central Government & Interview \\
\hline 6 & Junior Consultant & $\begin{array}{l}\text { Indonesian Utility } \\
\text { Company }\end{array}$ & Email correspondence \\
\hline 7 & $\begin{array}{l}\text { Head of Renewable Energy } \\
\text { Section }\end{array}$ & $\begin{array}{l}\text { DINAS ESDM East- } \\
\text { Indonesia }\end{array}$ & Interview \\
\hline 8 & Post-PhD & Indonesian University 1 & Interview \\
\hline 9 & $\begin{array}{l}\text { Several Staff Members, including } \\
\text { the head of the renewable } \\
\text { energy section }\end{array}$ & $\begin{array}{l}\text { DINAS ESDM Central- } \\
\text { Indonesia } 1\end{array}$ & Focus group/Interviews \\
\hline
\end{tabular}




\begin{tabular}{|c|c|c|c|}
\hline 10 & $\begin{array}{l}\text { Several Staff Members, including } \\
\text { the head of the renewable } \\
\text { energy section }\end{array}$ & $\begin{array}{l}\text { DINAS ESDM Central- } \\
\text { Indonesia } 2\end{array}$ & Focus Group/Interviews \\
\hline 11 & Policy Advisor & Dutch Embassy Indonesia & Interview \\
\hline 13 & Division Head & Procurement Agency & Interview \\
\hline 14 & Division Head & $\begin{array}{l}\text { ESDM Central } \\
\text { Government Indonesia }\end{array}$ & Interview \\
\hline 15 & Senior Advisor \& Team Leader & Indonesian NGO 2 & Skype interview \\
\hline 16 & Lecturer & Indonesian University 2 & Interviews \\
\hline 17 & Operator 1 & Hybrid Power Plant 1 & Interview \\
\hline 18 & Operator & Bio-digester System & Interview \\
\hline 19 & Operator 2 & Hybrid Power Plant 1 & Interview \\
\hline 20 & Village Head & Village Central-Indonesia & Interview \\
\hline 21 & Operator & Micro Hydro System 1 & Interview \\
\hline 22 & Operator & Micro Hydro System 2 & Interview \\
\hline 23 & Professor & Indonesian University 2 & Interview \\
\hline 24 & Junior Advisor & Indonesian NGO 2 & Personal correspondence \\
\hline
\end{tabular}




\section{References}

ADB (2016) 'Achieving universal Electricity access in Indonesia', Asian Development Bank, Manila.

Afifah, H. (2016) 'Evaluation of state-sponsored rural electrification project in Indonesia', MSc thesis, Eindhoven University of Technology, Eindhoven.

Amir, S. (2013) The Technological State in Indonesia: The Co-constitution of High Technology and Authoritarian Politics. Routledge, New York.

Bachmann, M., Vermeulen, P.A.M., Geurts, J.L.A. (2014) 'Scaling challenges at the base of the pyramid', in: Vermeulen, P., Hutte, E. (Eds) Strategic Challenges for the Base of the Pyramid, Edward Elgar, Cheltenham, pp.101-129.

Bedeian, A.G. (1980) Organizations, Theory and Analysis. The Dryden Press, Chicago.

Benitez, D., Estache, A. and Søreide, T. (2012) 'Infrastructure policy and governance failures', CMI Working Paper 2012:5, Christian Michelsen Institute, Bergen.

Bhamidipati, P.L., Hansen, U.E., Haselip, J. (2019, in press) 'Agency in transition: The role of transnational actors in the development of the off-grid solar PV regime in Uganda', Environmental Innovation and Societal Transitions.

Bhattacharyya, S.C. (2012) 'Review of alternative methodologies for analysing off-grid electricity supply', Renewable and Sustainable Energy Reviews 16:677-694.

Blum, N.U., Wakeling, R.S., Schmidt, T.S. (2013) 'Rural electrification through village grids Assessing the cost competitiveness of isolated renewable energy technologies in Indonesia', Renewable and Sustainable Energy Reviews, 22:482-496.

Bohte, J. \& Meier, K. (2000) 'Goal displacement: Assessing the motivation for organizational cheating', Public Administration Review, 60:173-182.

Braa, J., Hanseth, O., Heywood, A., Mohammed, W., Shaw, V. (2007) 'Developing health information systems in developing countries: The flexible standards strategy', MIS Quarterly 31(2):381-402.

Cosgrove-Davies, M., Cabraal, A. (1994) ‘Best practices for PV solar home system projects”, Proceedings of the IEEE 1st World Conference on Photovoltaic Energy Conversion Vol 2, 5-9 Dec. 1994. 
Ferrer-Martí, L., Garwood, A., Chiroque, J., Ramirez, B., Marcelo, O., Garfí, M., Velo, E. (2012) 'Evaluating and comparing three community small-scale wind electrification projects', Renewable and Sustainable Energy Reviews 16 (7):5379-5390.

Foster, C., Heeks, R. (2013) 'Innovation and scaling of ICT for the bottom-of-the-pyramid', Journal of Information Technology 28(4):296-315.

Fowlie, M., Khaitan,Y. Wolfram, C., Wolfson, D. (2018) ‘Solar Microgrids and Remote Energy Access: How Weak Incentives Can Undermine Smart Technology', Energy Institute at Haas,WP 295, University of California, Berkeley.

Frobisher, E. (2019) 'Unpacking the aid chain: Do donor rules help or hinder advocacy efforts in Kenya?', Opinion post, INCLUDE Knowledge Platform on Inclusive Development Policies, https://includeplatform.net/unpacking-the-aid-chain-do-donor-rules-help-or-hinder-advocacy-efforts-inkenya/?utm_source=Newsletter+INCLUDE\%3A+Knowledge+Platform+on+Inclusive+Development+Polici es\&utm_campaign=2035f4b090-

2017_12_Dec_COPY_01\&utm_medium=email\&utm_term=0_fe2205aa6a-2035f4b090-209793237\#

Global Business Guide Indonesia (2014a) ‘Going Local: Understanding Indonesia's Local Content Requirements', 5 May.

http://www.gbgindonesia.com/en/main/business updates/2014/upd going local understanding indonesia s local content requirements.php

Global Business Guide Indonesia (2014b) 'Renewable Energy in Indonesia - A Sleeping Giant'. http://www.gbgindonesia.com/en/energy/article/2014/renewable energy in indonesia a sleeping giant.p $\underline{\mathrm{hp}}$

Gray, J. (1998) 'The best-laid plans'. Review of "Seeing like a state” by J.C Scott, The New York Review of Books, 19 April.

Grindle, M.S. (ed.) (1980) Politics and Policy Implementation in the Third World. Princeton University Press, Princeton, NJ.

Guerreiro, S., Botetzagias, I. (2017) ‘Empowering communitie: the role of intermediary organizations in community renewable energy projects in Indonesia', Justice and Sustainability, 23 (2):158-177.

GVEP (2011) 'The history of mini-grid development in developing countries', Policy Briefing, GVEP International, London.

IEA (2017) Energy Access Outlook 2017. From Poverty to Prosperity. OECD/IEA. 
Ikejemba, E.C.X., Mpuan, P.B., Schuur, P.C., Hillegersberg, J. van, (2017) 'The empirical reality \& sustainable management failures of renewable energy projects in Sub-Saharan Africa (part 1)', Aparna Katre1* , Arianna Tozzi2 and Subhes Bhattacharyya3Renewable Energy 102(A):234240.

Jasanoff, S. and Kim, S.-H. (2015) Dreamscapes of Modernity: Sociotechnical Imaginaries and the Fabrication of Power. Univ of Chicago Press, Chicago.

Jigyōdan, K.K. (1993) Study on Utilization of Photovoltaic Hybrid Systems in Rural Areas in the Republic of Indonesia. Japan International Cooperation Agency, Tokyo.

Katre, A., Tozzi, A., Bhattacharyya, S. (2019, in press) 'Sustainability of community-owned minigrids: evidence from India', Energy, Sustainability and Society 9 (2): 1-17.

Kemendagri (2018) 'Rekapitulasi jumlah ppid provinsi, kabupaten dan kota', Indonesian Ministry of Home Affairs, Jakarta, 4 April. https://www.kemendagri.go.id/media/filemanager/2018/01/02/r/e/rekap jumlah ppid prov kab kota.pdf Kirchhoff, H., Kebir, N., Neumann, K., Heller, P.W., Strunz, K. (2016) ‘Developing mutual success factors and their application to swarm electrification: microgrids with $100 \%$ renewable energies in the Global South and Germany', Journal of Cleaner Production 128:190-200.

Korten, D.C. (1980) ‘Community Organization and Rural Development: A Learning Process Approach', Public Administration Review, Sept/Oct, 480-511. http://www.gbgindonesia.com/en/energy/article/2014/renewable energy in indonesia a sleeping giant.p $\underline{\mathrm{hp}}$

Kumar, A., Ferdous, R., Luque-Ayala, A., McEwan, C., Power, M., Turner, B. , Bulkeley, H., (2019) 'Solar energy for all? Understanding the successes and shortfalls through a critical comparative assessment of Bangladesh, Brazil, India, Mozambique, Sri Lanka and South Africa', Energy Research and Social Science 48: 166-176.

Lewis, B. D. (2017) 'Intergovernmental fiscal transfers and local incentives and responses: The case of Indonesia, Fiscal Studies 38: 111-139.

Lewis, B.D. (2015) 'Decentralising to villages in Indonesia: Money (and other) mistakes', Public Administration and Development, 35: 347-359.

Lewis, B.D., McCulloch, N., Sacks, A. (2016) 'Measuring local government service delivery performance: Challenges and (partial) solutions in Indonesia', Journal of International Development, 28: 808-817. 
Lewis B.D., Smoke P. (2017) 'Intergovernmental fiscal transfers and local incentives and responses: The case of Indonesia', Fiscal Studies 38(1): 111-139.

Mandelli S., Mereu R. (2013) ‘Distributed generation for access to electricity: "Off-main-grid” systems from home-based to microgrid', in: Colombo, E., Bologna, S., Masera, D. (Eds) Renewable Energy for Unleashing Sustainable Development. Springer, Cham, pp 75-98.

Mandelli, S., Barbieri, J., Mereu, R., Colombo, E. (2016) 'Off-grid systems for rural electrification in developing countries', Renewable and Sustainable Energy Reviews 58:1621-1646.

Marquardt, J. (2014) 'How sustainable are donor-driven solar power projects in remote areas?', Journal of International Development 26: 915-922.

Marquardt, J. (2017) How Power Shapes Energy Transitions in Southeast Asia: A Complex Governance Challenge. Routledge, Abingdon.

McCawley, P. (2006) 'Governance in Indonesia: Some comments', Discussion paper 38, Asian Development Bank Institute, Tokyo.

Mcloughlin, C., Batley, R., (2012) 'The effects of sector characteristics on accountability relationships in service delivery', WP 350, ODI, London.

Mehang, T.S., Tanoto, Y., Santoso, M. (2016) 'Potential of small size hybrid diesel-photovoltaic to improve sub-district supply duration in East Sumba, Indonesia', International Journal of Renewable Energy Research, 6 (3):964-969.

Mawhood, R., Gross, R. (2014) 'Institutional barriers to a 'perfect' policy: A case study of the Senegalese Rural Electrification Plan', Energy Policy 73:480-490.

Moon, S. (2015) 'Building from the outside in: Sociotechnical imaginaries and civil society in New Order Indonesia', in: Jasanoff, S. and Kim, S.-H. (Eds) op. cit. ,pp.174-198.

Negara, S.D. (2016) 'The impact of local content requirements on the Indonesian manufacturing industry', ISEAS Economics Working Paper 2016:4, ISEAS - Yusof Ishak Institute, Jakarta.

Noorderhaven, N. (1995) Strategic Decision Making. Addison-Wesley, Wokingham.

Nugroho, H , Fei-Lu, S., Firmansyah (2017) 'Developing renewable energy in developing countries: A lesson from Indonesia', Energy Sources, Part B: Economics, Planning and Policy, 12(4): 318-325.

Odarno, L. (2017) 'Electrifying Africa with mini-grids: Five lessons from Tanzania’, blogpost, World Resources Institute. https://www.wri.org/blog/2017/10/electrifying-africa-mini-grids-five-lessons-tanzania 
Palit, D., Bandyopadhyay, K.R., (2017) 'Rural electricity access in India in retrospect: A critical rumination', Energy Policy 109:109-120.

Palit, D., Chaurey, A., (2011) 'Off-grid rural electrification experiences from South Asia: Status and best practices', Energy for Sustainable Development 15(3):266-276.

Pressman, J.L. and Wildavski, A. (1973) Implementation. University of California, Berkeley.

Pritchett, L., Woolcock, M. (2004) 'Solutions when the solution is the problem: Arraying the disarray in development', World Development 32 (2):191-212.

Putra, A.W., Kamandika, E., Rosyadi, S. Purwadi, A., Haroen, Y. (2017) 'Study and design of hybrid off-grid PV-generator power system for administration load and communal load at three regions in Indonesia', Conference on Power Engineering and Renewable Energy, 29-30 Nov, 2016, Yogyakarta.

Purwanto, W.W., Afifah, N. (2016) 'Assessing the impact of techno-socioeconomic factors on sustainability indicators of micro-hydropower projects in Indonesia: A comparative study', Renewable Energy, 93:312-322.

PwC (2013) Power in Indonesia $2^{\text {nd }}$ edition, Investment and Taxation Guide, Price Waterhouse Coopers, Jakarta.

Quick, S.A. (1980) 'The paradox of popularity: “Ideological” program implementation in Zambia', in M.S. Grindle (ed.) op.cit., pp.40-63.

Ranzanici A. (2013) 'Sustainability comparison between EnDev and non-EnDev micro-hydro power (MHPP) in Indonesia', MSc thesis, Universidad Politecnica, Madrid.

Resh, W.G., Marvel, J.D. (2012) 'Loopholes to load-shed: Contract management capacity, representative bureaucracy, and goal displacement in federal procurement decisions', International Public Management Journal 15(4):525-547.

Retnanestri, M., Outhred, H. (2013) 'Acculturation of renewable energy technology into remote communities: Lessons from Dobrov, Bourdieu, and Rogers and an Indonesian case study', Energy, Sustainability and Society 3(1):1-13.

Sahn, D.E., Stifel, D.C. (2003) 'Urban-Rural Inequality in Living Standards in Africa', Journal of African Economies 12(4):564-597. 
Sato, T., Ide, J., Isa, M.A., Fujimoto ,T., Shimatani, Y. (2017) ‘Challenge for sustainable electrification; Respecting the local tradition in Ciptagelar village, West Java, Indonesia', Energy Procedia, 141:368-372.

Scott, A., Seth, P. (2013) 'The political economy of electricity distribution in developing countries: a review of the literature', ODI, London.

Schmidt, T.S., Blum, N.U., Sryantoro Wakeling, R. (2013) 'Attracting private investments into rural electrification - A case study on renewable energy based village grids in Indonesia', Energy for Sustainable Development, 17(6), 581-595.

Setiawan, A.D. (2018) Responsible Innovation: From Concept to Application. PhD thesis, Eindhoven University of Technology, Eindhoven.

Shezan, S.K.A., Al-Mamoon, A., Ping, H.W. (2017) 'Performance investigation of an advanced hybrid renewable energy system in Indonesia', Environmental Progress \& Sustainable Energy 37 (4):1424-1432.

Sovacool, B.K. (2012) 'Design principles for renewable energy programs in developing countries', Energy \& Environmental Science 5: 9157-9162.

Sovacool, B.K., Drupady, I.M. (2012) Energy Access, Poverty, and Development: The Governance of Small-scale Renewable Energy in Developing Asia. Routledge, London.

Thomas, E.A. (ed.) (2016) Broken Pumps and Promises. Incentivizing Impact in Environmental Health. Springer, Cham.

Tumiwa F., Imelda, H. (2014) 'Sustainable Energy Finance in Indonesia', WWF. http://awsassets.wwf.or.id/downloads/sustainable_energy_finance_in_indonesia.pdf

Ulsrud, K., Rohracher, H., Winther, T., Muchunku, C., Palit, D. (2018). 'Pathways to electricity for all: What makes village-scale solar power successful? Energy Research \& Social Science, 44:32-40.

Ulsrud, K., Winther, T., Palit, D., Rohracher, H., Sandgren, J. (2011) 'The solar transitions research on solar mini-grids in India: Learning from local cases of innovative socio-technical systems', Energy for Sustainable Development 15 (3): 293-303.

Urmee T., Anisuzzaman, Md. (2016) 'Social, cultural and political dimensions of off-grid renewable energy programs in developing countries', Renewable Energy, 93:159-167. 
Valer, L.R., Manito, A.R.A., Selles Ribeiro, T.B., Zilles, R., Pinho, J.T. (2017) 'Issues in PV systems applied to rural electrification in Brazil', Renewable and Sustainable Energy Reviews 78: 1033-1043.

Wahyuni, N.S., Wulandari, S., Wulandari, E., Pamuji, D.S. (2015) 'Integrated communities for the sustainability of renewable energy application: Solar water pumping system in Banyumeneng village, Indonesia, Energy Procedia 79:1027-1032.

Wardhani, R., Rossieta, H., Martani, D. (2017) ‘Good governance and the impact of government spending on performance of local government in Indonesia', International Journal of Public Sector Performance Management 3(77):77-102.

Warner, W., Havens, A. (1968) Goal displacement and the intangibility of organizational goals. Administrative Science Quarterly 12(4):539-555.

Wells, L.T. (2007) Private Power in Indonesia, Bulletin of Indonesian Economic Studies, 43(3):341364.

Welsch, M., Bazilian, M., Howells, M., Divan, D., Elzinga, D., Strbac, G., et al. (2013) 'Smart and just grids for sub-Saharan Africa: exploring options', Renewable and Sustainable Energy Reviews 20:336-352.

Wild, L., Chambers, V., King, M., Harris, D. (2012) 'Common constraints and incentive problems in service delivery', WP 351, ODI, London.

Winter, S.G., Szulanski, G. (2001) 'Replication as strategy', Organization Science 12(6): 730-743.

World Bank (2003) 'Scaling-Up the impact of good practices in rural development: A working paper to support implementation of the World Bank's rural development strategy'. Report 26031, Agriculture \& Rural Development Department, World Bank, Washington, D.C.

World Bank (2005) Electricity for all: Options for Increasing Access in Indonesia, The World Bank Office, Jakarta.

Yurnaidi, Z. (2010) 'Opportunities and challenges of renewable energy and distributed generation promotion for rural electrification in Indonesia', Green Energy and Technology 44:102-107. 


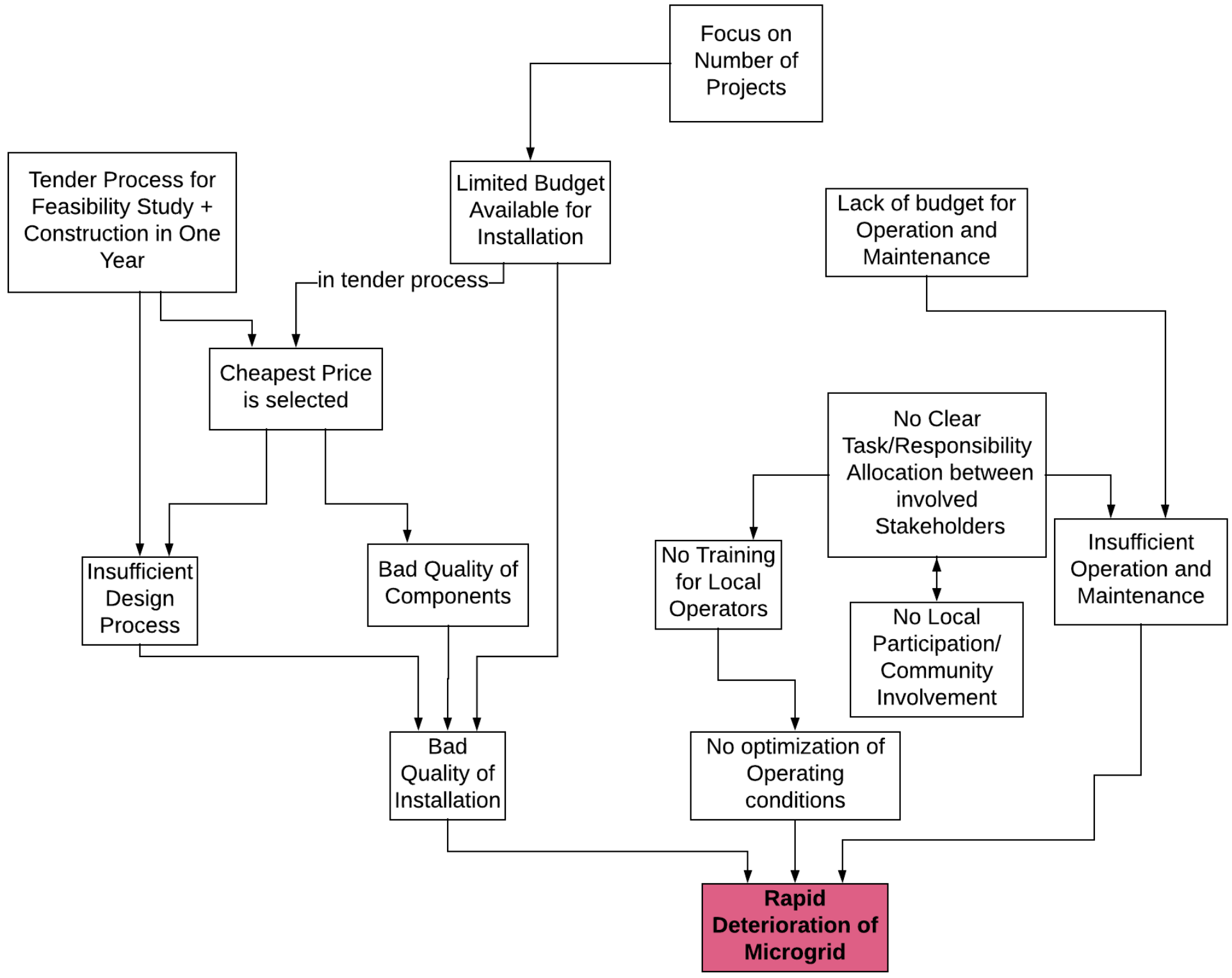

Figure 1: Diagram of reasons highlighted in literature for rapid deterioration of Indonesian microgrids.

Source: compiled by authors. 


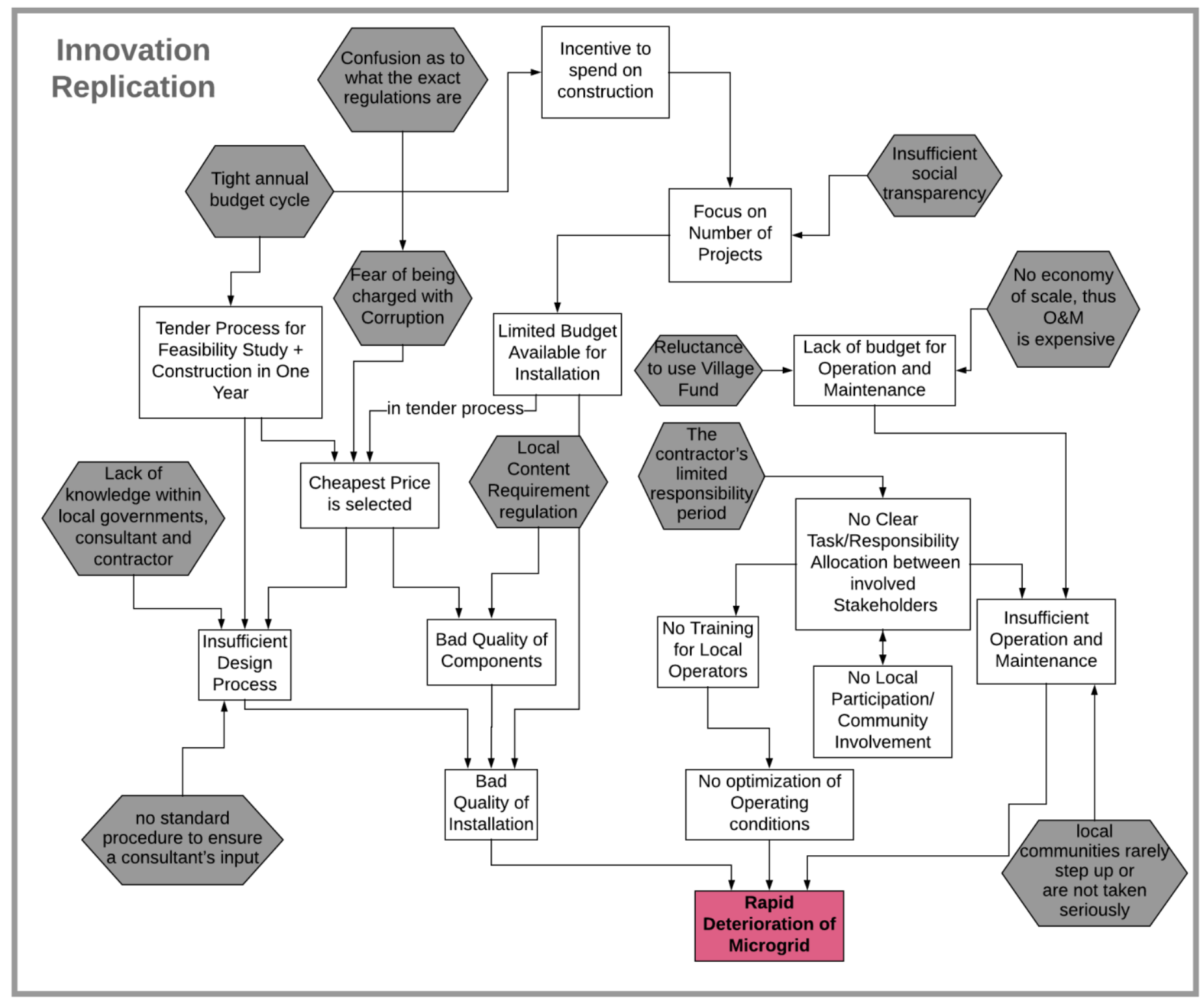

Figure 2: Reasons for rapid deterioration of microgrids (white rectangles) caused by problems with core and adaptation processes during large scale replication (grey hexagons)

Source: authors. 


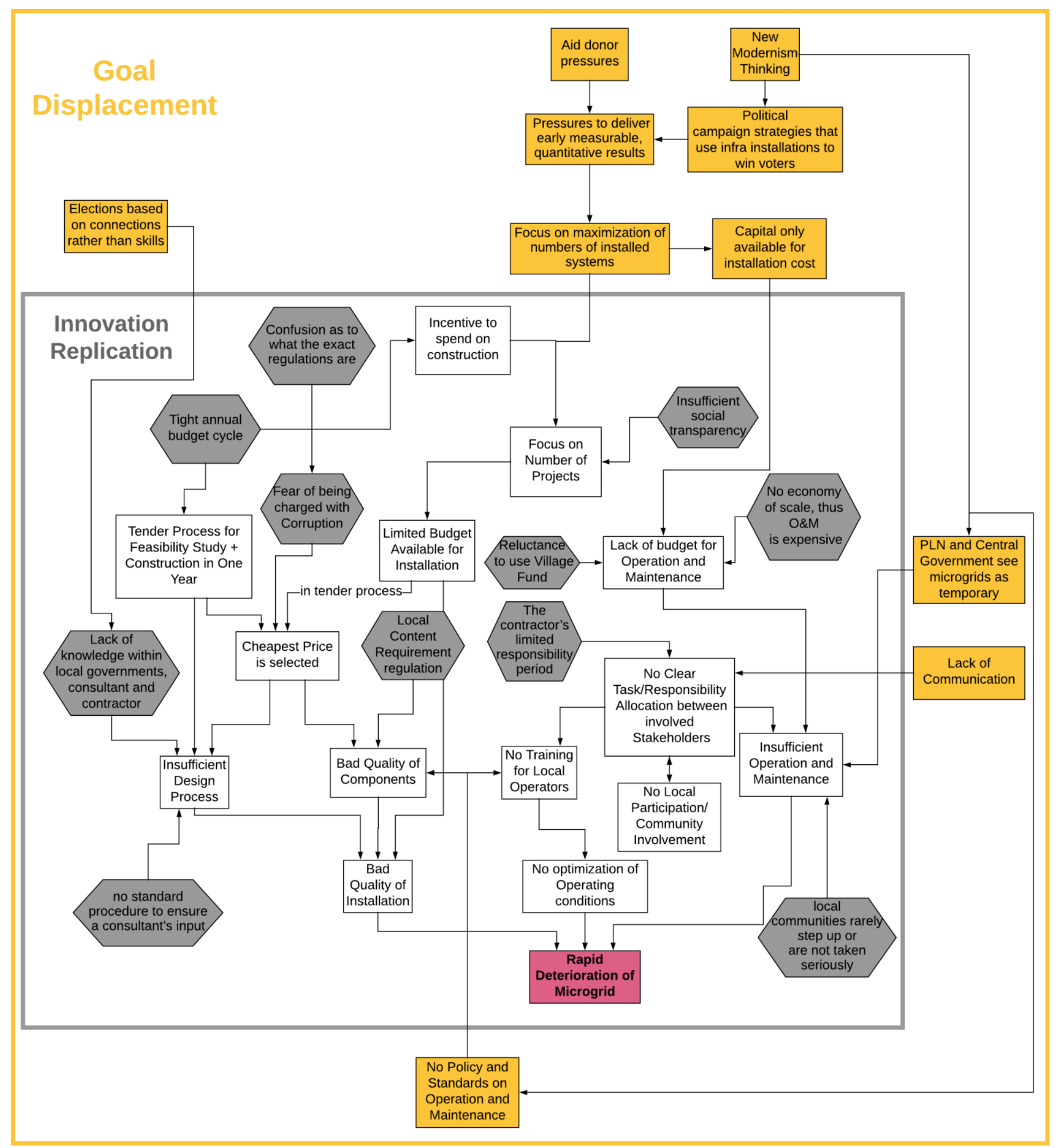


Figure 3: Reasons for rapid deterioration of microgrids: proxy causes (white rectangles), underlying issues with core and adaptation processes (grey hexagons) and underlying institutional causes (orange rectangles).

Source: authors. 
Notes

[1] Project proposals are not always initiated by a hamlet; sometimes, a local university or central/local government proposes a microgrid as part of a development or electrification program [7],[10],[13],[14].

[2] DAK (Dana Alokasi Khusus, or Special Purpose Grant) is central government funding for construction of specific projects.

[3] In 2018, a scheme was introduced under DAK to provide funding for rehabilitation of completely dysfunctional micro-hydro grids. However, if a local government applies for funds under the rehabilitation scheme, the money will only become available the next year. Thus, the microgrid system will be inoperative for yet another year [9],[15]. This new policy is therefore not expected to ameliorate the problem substantially.

[4] Local governments receive $70 \%$ of their annual budget funding from the DAU (general purpose grant) and DAK (special purpose grant). The rest comes from taxes and other own revenue generation (Lewis and Smoke, 2017). DAK can be used for, among other things, microgrid construction, but not for maintenance and repair costs which have to be paid by the revenues raised by local governments themselves (Lewis, 2017).

[5] Energi Baru Terbarukan dan Konservasi Energi (Department of Renewable Energy and Energy Conservation)

[6] Kementerian Energi dan Sumber Daya Mineral Republik (Ministry of Energy and Mineral Resources)

[7] Including: the Ministry of Finance which oversees energy sector loans and subsidies, the Ministry of State-

Owned Enterprises which is a shareholder of PLN, the national planning agency BAPPENAS, the Ministry of People's Welfare, and other ministries such as Agriculture for hydro projects or Forestry for biomass projects (Marquardt, 2017). 